\title{
Future of excavations for nuclear power projects
}

\author{
JK Jain \\ Rajasthan Atomic Power Project Unit-7\&8 \\ Rawatbhata, Rajasthan \\ jivendrakjain@npcil.co.in
}

\begin{abstract}
The beauty of science \& technology is that as in a while there comes an invention that calmly replaces on existing paradigm and brings about profound changes in the every sphere of life including day-by-day innovations during implementation of engineering projects with continuous improvements toward excellence.
\end{abstract}

\section{INTRODUCTION}

Atomic Energy activities in the country are governed by the Atomic Energy Act. The commercial nuclear power programme of the first stage (comprising of Pressurised Heavy Water Reactors - PHWRs and imported Light Water Reactors - LWRs), is being implemented by Nuclear Power Corporation of India Limited (NPCIL) and the second phase (Comprising of Fast Breeder Reactors) by Bhartiya Nabikiya Vidyut Nigam Limited (BHAVINI), both companies owned fully by the union government in accordance with the provisions of the act.

In India, nuclear energy development began with the objectives of peaceful uses of atomic energy in improving the quality of life of the people \& to achieve self-reliance in meeting energy needs. It is expected to play a significant role in meeting the huge electricity demand of the country.

Present, installed operating capacity of nuclear power is 6780 MWe including two 1000 MWe LWR at Kudankulam. Projects under construction are Kakrapar Atomic Power Project units $3 \& 4$ ( 2 x $700 \mathrm{MWe})$, Rajasthan Atomic Power Project units $7 \& 8(2 \times 700 \mathrm{MWe})$ PHWRs, Kudankulam Atomic Power Project units 3\&4 (2x1000 MWe) \& Prototype Fast Breeder Reactor PHBR (500 MWe). Construction of Gorakhpur Haryana Anu Vidhyut Pariyojna units $1 \& 2$ (2 $\mathrm{x} 700 \mathrm{MWe}$ ) is also about to start where pre-project activities are under progress. Future expansion is planned to achieve as estimated by Department of Atomic Energy as 63 GWe by the year 2032 .

Considering the highlighted highly ambitious Nuclear Energy development programme, it is the need of hour to reduce the gestation period of Project implementation to an optimum level and even to cross the international bench marking.

Our country has presently developed comprehensive capabilities in all aspects of nuclear power from sitting, design, construction, operation of NPPs. Comprehensive multi-dimensional R\&D facilities have been set up by NPCIL. Capabilities have also been developed in front \& back ends of the fuel cycle, from mining, fuel fabrication, storage of spent fuel, reprocessing \& waste management. Infrastructures for other inputs like heavy water, Zirconium
Components, control and instrumentations etc. have also been established. Excellent human resources \& training infrastructures have been developed for the specialized skill needed for nuclear power.

\section{IMPORTANCE OF EXCAVATION TECHNIQUES DURING CONSTRUCTION OF NPPS}

While optimizing the project gestation period, excavation time line during project implementation also plays vital role along with quality of excavation to achieve competent founding strata. Hence, it is paramount to note that excavation techniques should not disturb the underlying founding strata after completion of excavation simultaneously with the speed of excavation to achieve specified monthly target to minimize/optimize the excavation duration during civil construction of NPPs.

\section{PRE-REQUISITES FOR EXCAVATION OF NPPS}

Completion of specified Geological and Geo-physical studies including Seismological Mapping of the area and completion of specified geo-technical studies.

\section{EXCAVATION OF NPPS}

Excavation/Earthwork has to be done to the specified lines and levels. The earthwork shall also require engineered temporary sheet piling or sheeting, bracing and shoring, to maintain the excavated pits etc as per the properties of soil and depth of the excavated pits including substantial barricading for ensuring safety aspects.

The excavation in certain areas of the plant is to be taken-up in two stages. Stage-I excavation comprises area grading and road excavations of the main plant yard. StageII excavation where specified on the drawings shall begin only after Stage-I excavation has been completed. This will comprise line drilling/pre-shearing of vertical faces of excavations of the structure and areas as specified and subsequent drilling, blasting and removal of muck up to the lines and grades as specified in accordance with the construction requirements.

\section{EXCAVATION IN SOIL}

This includes earth, murrum, top deposits of agricultural soil, reclaimed soil, clay, sand or any combination thereof, soft and hard murrum, shingle etc which is loose enough to be removed with spades, shovel, pick axes, poclain \& poclain mounted rippers. Boulders in all volumes up to $1 \mathrm{CuM}$, found during excavation shall also fall under this classification. This shall also include all materials, hard conglomerate, all decomposed weathered 
rock, highly fissured rock and other varieties of soft rock, which can be removed with pick axes, crowbars, wedging and hammering $\&$ other mechanical equipments with some difficulty.

\section{EXCAVATION IN HARD ROCK}

The total excavation work in hard rock shall be categorized in the following four (4) categories during NPP Construction:

- Excavation in hard rock using general and free blasting

- Excavation in hard rock using controlled blasting. During controlled blasting line drilling and/or preshearing, are adopted for reducing over break and for preventing damage to rock beyond the limits of excavation. As a part of control blasting the PPV limitations to the extent of $3 \mathrm{~mm}$ per second to protect nearby sensitive structures of existing operating stations. The same is to be monitored by using engineering seismographs (such as seismograph model VS1600 or equivalent), sensors and such electronic devices to record the induced blast vibration in three mutually perpendicular directions to assess and monitor the impact of the blast on the adjacent structures and for carrying out suitable adjustment in the quantum of charge with suitable delays and making a engineered blast charge pattern to prevent any damage to existing structures along with speed of blasting. Biggest blasting operation was planned and taken-up successfully at RAPP-7\&8 Project with NIRM Guidelines to achieve a quantum of muck to the extent of 10,000 Cum in a single blast. Peak monthly out-put achieved during excavation of RAPP-7\&8 was 2 Lacs CuM for maintaining construction schedule requirements.

- Excavation in hard rock by blasting using mufflers (muffled blasting).

- Excavation in hard rock without blasting i.e. by wedging/barring/hydraulic splitter.

\section{StABILITY OF EXCAVATION}

It solely depends on ascertaining of the nature of materials to be excavated and difficulties likely to be encountered in executing the excavation. Engineered Coffer dams, sheeting and shoring, bracing and maintaining suitable slopes, draining etc. shall be provided and installed for the excavated pits as per construction site requirements of NPPs.

\section{SCHEME FOR HANDLING GROUND WATER AND EXCAVATED MUCK}

The scheme of dewatering has to be designed to ensure no ponding of water on the excavated surface while carrying out excavation, concreting and other related construction works. Though there are different systems of dewatering available, depending on the permeability of the soil system suitable dewatering system has to be selected and implemented for facilitating the underground construction of NPPs. Well defined scheme for mucking operations of excavated material is also very important with identified routes considering vehicles mobility and location of dumping yard for speedy muck disposal operations to expedite the work at the desired pace.

\section{CONCLUSION}

To conclude, it is very essential to have proper selection of excavation methodologies, deployment of resources, identified mucking routes and its dumping yard with proper dewatering system for expeditious completion of excavation of future NPPs to meet the scheduled targets for optimising gestation period of project construction. 